\title{
PERAN ORANG TUA DALAM PENDIDIKAN AGAMA PADA KELUARGA ANAK USIA SEKOLAH DASAR DI DUSUN CANDI REJO, DESA SARDONOHARJO, NGAGLIK, SLEMAN
}

\author{
Zikry Septoyadi ${ }^{1}$, Vita Lastriana Candrawati ${ }^{1}$ \\ ${ }^{1}$ Pendidikan Agama Islam, Fakultas IImu Agama Islam, Universitas Islam Indonesia \\ Yogyakarta
}

\begin{abstract}
ABSTRAK
Latar belakang penelitian ini adalah Dewasa ini, ilmu pengetahuan dan teknologi semakin berkembang pesat dan tidak terlepas dari aktivitas kehidupan sehari-hari. Manusia dapat menemukan berbagai macam alat atau mesin yang dapat digunakan untuk membantu pekerjaannya, sehingga lebih mudah, cepat, dan akurat. Pengaruh era distrupsion terhadap keluarga ini tentunya ada yang berdampak positif dan ada juga yang berdampak negatif. Penelitian ini bertujuan Menjadi bahan pertimbangan baru bagi penentu kebijakan sekolah atau pemangku kepentingan lainnya terkait dengan upaya membumikan Peran Orang Tua dalam pendidikan agama pada keluarga pada Anak Usia Sekolah Dasar. Penelitian ini adalah penelitian lapangan field research yang bersifat kualitatatif. Teknik pengumpulan data menggunakan teknik observasi, wawancara, dan dokumentasi. Hasil penelitian peran orang tua dalam pendidikan agama pada keluarga anak usia sekolah dasar di dusun candi rejo, desa sardonoharjo, ngaglik, sleman. Peneliti menyimpulkan bahwa penanaman yang di lakukan dalam pendidikan keluarga di dusun Candi Rejo ada beberapa faktor yang memperkuat anak dalam meningkatkan semangat dalam beribadah antara lain hadiah, takut di beri hukuman, pembiasaan nasihat kepada anak dan doktrin dalil agama yang membuat anak menjadi semangat dalam beribadah. Hal-hal yang menghambat bagi anak dalam beribadah dengan beberapa faktor yang ada antara lain kecanggihan tekhnologi, bermain dengan sesama teman, adanya sikap malas dan di biarkan oleh orang tua, tidak dekat nya rumah dengan lokasi masjid, dan dunia game menjadi faktor yang paling kuat menghambat nya anak untuk beribadah.
\end{abstract}

Kata kunci: Pendidikan Keluarga, Anak-anak, Sekolah Dasar

\begin{abstract}
The background of this research is that today, science and technology are growing rapidly and cannot be separated from the activities of daily life. Humans can find various kinds of tools or machines that can be used to help their work, making it easier, faster and more accurate. The influence of the era of disruption to this family of course has a positive impact and some has a negative impact. This study aims to become a new consideration for school policy makers or other stakeholders related to efforts to ground the role of parents in religious education in families in elementary school age children. This research is a qualitative field research. Data collection techniques using observation, interview, and documentation techniques. The results of the research on the role of parents in religious education in families of elementary school age children in Candi Rejo hamlet, Sardonoharjo village, Ngaglik, Sleman. The researcher concluded that the cultivation carried out in family education in Candi Rejo hamlet were several factors that strengthened children in increasing their enthusiasm for worship, including gifts, fear of being punished, habituation of advice to children and religious doctrine that made children enthusiastic in worship. The things that hinder children from praying with several factors include technological sophistication, playing with friends, laziness and being ignored by parents, not being close to the house to the mosque, and the world of games being the strongest factors. hinder his children to worship.
\end{abstract}


Keywords: Family Education, Children, Elementary School

\section{PENDAHULUAN}

Dewasa ini, ilmu pengetahuan dan teknologi semakin berkembang pesat dan tidak terlepas dari aktivitas kehidupan sehari-hari. Manusia dapat menemukan berbagai macam alat atau mesin yang dapat digunakan untuk membantu pekerjaannya, sehingga lebih mudah, cepat, dan akurat. Pengaruh era distrupsion terhadap keluarga ini tentunya ada yang berdampak positif dan ada juga yang berdampak negatif. Dampak positif yang dirasakan seiring kemajuan ilmu dan teknologi adalah banyaknya temuan alat-alat mekanik yang dapat membantu setiap anggota keluarga dalam menjalankan tugasnya. Sedangkan untuk pengaruh negatif yang disebarkan oleh post-trust ini dalam keluarga adalah manusia lebih mendewakan rasio dan akal yang bersifat materialis, individualis, liberalis, dan hedonis yang berasal dari mana saja mulai dari pengaruh lingkungan masyarakat, teman sebaya, internet, media sosial, siaran televisi yang tidak mendidik, dan penyakit masyarakat lainnya yang dapat mempengaruhi pola pikir, perilaku, kebiasaan, maupun gaya hidup pada diri seseorang, menjadikan manusia semakin jauh dari Tuhan dan ajaran agamanya.

Mengingat keluarga sebagai fase awal pendidikan, dalam menghadapi berbagai tantangan zaman seperti saat ini. Tanggung jawab pendidikan pada dasarnya tidak bisa dipikulkan begitu saja kepada orang lain. Latihan-latihan dan pembinaan terutama dalam hal keagamaan hendaklah dilakukan sedemikian rupa sehingga menumbuhkan nilai-nilai yang sangat diperlukan dalam pertumbuhan anak, mengingat anak merupakan amanat dari Allah Swt yang harus dipikul oleh pundak orang tua. Orang tua bertanggung jawab atas terlaksananya amanat ini. Bila orang tua salah dalam mendidik anak, kesalahan itu akan menyebabkan kerusakan yang nyata dan kelalaian yang serius.

Dalam kenyataannya, keluarga tidak sedikit yang gagal dalam membina keluarga sesuai dengan yang dikehendaki oleh ajaran islam. Kegagalan demikian akan berpengaruh pula terhadap fungsi keluarga sebagai pusat pendidikan. Untuk mengatasi hal yang demikian dibutuhkan pengertian dan kesadaran bahwa keluarga berperan sebagai tempat pendidikan anak-anak. Orang tua mempunyai pengaruh yang sangat besar terhadap pembentukan kepribadian anak khususnya di dalam beribadah orang tua juga harus memberikan pengarahan, perhatian, tauladan, sarana serta bimbingan yang cukup bagi anak dan mengawasi serta mengevaluasi ibadahnya.

Rendahnya tingkat ibadah seseorang terutama pada anak akan menimbulkan berbagai masalah salah satunya adalah kemerosotan akhlak. Gejala kemerosoton akhlak pada saat ini telah banyak menimpa umat islam dari berbagai kalangan usia mulai dari orang tua, remaja, maupun pada anakanak. Apabila melihat apa yang dialami anak-anak sekarang, seperti kenakalan dan penyimpangan, juga kelengahan dan ketidakpedulian orang tua kepada mereka tentu hal ini perlu menjadi perhatian bagi kita semua, baik pemerintah, orang tua, guru, seluruh elemen masyarakat. Salah satu hal yang dapat meminimalisir gejala kemerosotan akhlak pada anak adalah dengan ibadah, Ibadah dan akhlak merupakan dua hal yang tidak dapat dipisahkan antara satu dengan yang lainnya. Dalam melakukan ibadah mengandung implikasi akhlak, ketika seseorang terbiasa melakukan ibadah dengan benar dan memahami makna ibadah tidak hanya sekedar ritual saja maka dalam mempraktikkan ibadahnya akan timbul kesadaran atau pengamalan ibadahnya baik terhadap dirinya sendiri maupun masyarakat sekitar.

Berdasarkan hasil pengamatan dan observasi permasalahan di Dusun Candi Rejo, Desa Sardonoharjo. Peneliti dapat menyimpulkan bahwa beberapa hal yang mesti di jadikan landasan bagi 
orang tua untuk berperan aktif dalam meningkatkan nilai-nilai religiusitas di dalam lingkup keluarga, dengan ada nya transformasi nilai-nilai religiusitas dalam sikap, perilaku, serta pembelajaran yang di lakukan oleh orang tua kepada anak akan menimbulkan dampak yang begitu signifikan terhadap kehidupan seharihari di dalam keluarga terutama bagi anak-anak. Namun penanaman nilainilai religiusitas belum begitu signifikan di Dusun Candi Rejo dengan beberapa faktor yang menjadi diskursus dalam penanaman nilai-nilai religiusitas di dalam lingkup keluarga, antara lain : pertama, dalam ranah letak geografis antara rumah dengan masjid menjadi pengaruh yang sangat signifikan dalam melihat peran keluarga dalam pembinaan nilai-nilai religiusitas seperti shalat dan membaca al-quran. Kedua, dalam ranah internalisasi keluarga yang tidak sedikit dari beberapa keluarga masih belum menjadi tauladan dalam mencerminkan sikap nilai-nilai religiusitas seperti orang tua shalat di masjid agar dapat di contoh dengan anak, orang tua ikut majelis agar anak memiliki kesadaran untuk mengikuti, orang tua mengaji bersama tetangga agar anak memiliki kesadaran untuk mengikuti. Ketiga, dalam ranah kesibukan kerja ataupun lainnya yang di miliki keluarga, sehingga anak tidak dapat di jadikan prioritas dalam mentransformasikan nilai-nilai religiusitas seperti shalat dan membaca al-quran kepada anak lewat lingkup keluarga. Beberapa faktor yang membuat peran keluarga sangat di butuhkan dalam mentransformasikan nilai-nilai religiusitas kepada anak sangat penting bagi pertumbungan dan perkembangan anak serta kehidupan sehari-hari dalam lingkup keluarga. Beberapa contoh di antara lain, saat ibadah shalat jamaah di masjid-masjid Candi Rejo masih tidak terlalu banyak orang tua mengajak anak-anak yang mengisi masjid, walaupun TPA di beberapa masjid ada yang aktif dalam pembelajaran Iqro dan Al-Quran bagi anak-anak, namun hal ini tidak menjadi tolak ukur dalam pembinaan peran orang tua bagi anak-anak nya. Dan ada contoh berikut nya seperti pada acara tahlil, pengajian, maulid, haul, dan syukuran/selamatan sangat sedikit para orang tua mengajak anak-anak nya dalam mengenalkan sebuah tradisi kultur islam, sehingga dengan pengenalan berupa kultur keagamaan yang ada di masyarakat anak-anak dapat mengenal sejak dini sebuah kultur islam yang akan menambah pengetahuan serta menambah daya spritualitas yang baik bagi perkembangan dan pertumbuhan anakanak.

Berpijak dari apa yang telah dipaparkan diatas maka penulis tertarik untuk meneliti dan mengkaji lebih dalam tentang "PERAN ORANG TUA DALAM PENDIDIKAN AGAMA PADA KELUARGA ANAK USIA SEKOLAH DASAR DI DUSUN CANDI REJO, DESA SARDONOHARJO, NGAGLIK, SLEMAN"

\section{METODE PENELITIAN}

Metode yang digunakan dalam penelitian ini adalah metode kualitatif yaitu meliputi kegiatan pengamatan, wawancara atau penelaahan dokumen ${ }^{[1]}$ Metode kualitatif lebih menekankan analisisnya pada proses penyimpulan deduktif dan induktif serta pada analisis terhadap dinamika hubungan antar fenomena yang diamati, dengan menggunakan logika ilmiah ${ }^{[2]}$. Pendekatan dalam penelitian ini menggunakan deskriptif kualitatif, yaitu penelitian yang bertujuan menggambarkan secara sistematik dan akurat fakta dan karakteristik mengenai populasi atau mengenai bidang tertentu. Penelitian ini berusaha menggambarkan situasi dan kejadian ${ }^{[3]}$.

Dalam melaksanakan penelitian ini, peneliti mengambil tempat di Dusun Candi Rejo, Desa Sardonoharjo. Dengan pertimbangan tersedianya data untuk memecahkan masalah dalam penelitian ini. Dalam penelitian ini, subjek penelitian ini adalah 10 keluarga yang merupakan masyarakat dari tiga dusun di Dusun Candi Rejo, Desa Sardonoharjo. Untuk memperolah informasi mengenai "Peran orang tua dalam pendidikan agama pada keluarga Anak Usia Sekolah di Dusun Candi Rejo, Desa Sardonoharjo". Tahapan pertama, akan dilakukan tinjauan langsung dengan mewawancarai 10 keluarga di 
Dusun Candi Rejo, Desa Sardonoharjo. Tahapan kedua diberikan lembar evaluasi atau post test dengan mewawancarai beberapa keluarga. Melakukan analisis terhadap hasil wawancara dan lembar evaluasi.

Pada penelitian ini, untuk mengetahui keabsahan data, penulis menggunakan teknik triangulasi. Triangulasi merupakan suatu teknik pengumpulan data yang bersifat menggabungkan dari berbagai teknik pengumpulan data dan sumber data yang telah $\mathrm{ada}^{[4]}$. Jika melakukan pengumpulan data dengan triangulasi, maka sebenarnya peneliti mengumpulkan data sekaligus menguji kredibilitas data, yaitu mengecek kredibilitas data dengan berbagai teknik pengumpulan data dan berbagai sumber data ${ }^{[5]}$. Pada penelitian ini, penulis menggunakan triangulasi teknik:

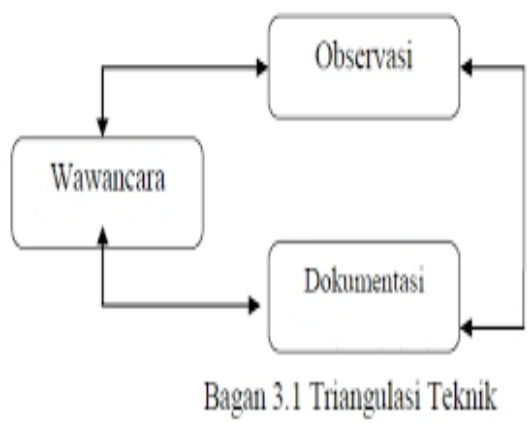

\footnotetext{
Bagan 1. Triangulasi Teknik ${ }^{[6]}$

Triangualasi teknik adalah penggunaan beragam teknik pengungkapan data yang dilakukan kepada sumber data. Menguji kredibilitas data dengan triangulasi teknik yaitu mengecek data kepada sumber yang sama dengan teknik yang berbeda. Misalnya, mengungkapkan data tentang aktifitas siswa di kelas dengan teknik wawancara, lalu dicek dengan observasi ke kelas melihat aktivitas siswa, kemudian dengan dokumentasi. Bila ternyata diperoleh situasi yang berbeda maka peneliti perlu melakukan diskusi lebih lanjut dengan sumber data atau yang lain untuk memastikan data yang dianggap benar ${ }^{[7]}$.

Teknik analisis data adalah proses mencari dan menyusun secara sistematis data yang diperoleh dari hasil wawancara, catatan lapangan, dan bahan-bahan lain sehingga dapat
}

dengan mudah dipahami dan temuannya dapat diinformasikan kepada orang lain.

Pada penelitian kualitatif, data yang telah dikumpulkan dan didapatkan akan dianalisis dengan pendekatan kualitatif model interaktif yang terdiri dari tiga tahapan yaitu reduksi data, penyajian data, dan penarikan kesimpulan atau verifikasi. Proses analisis data dalam penelitian dapat dilihat pada gambar 1.1 berikut ini:

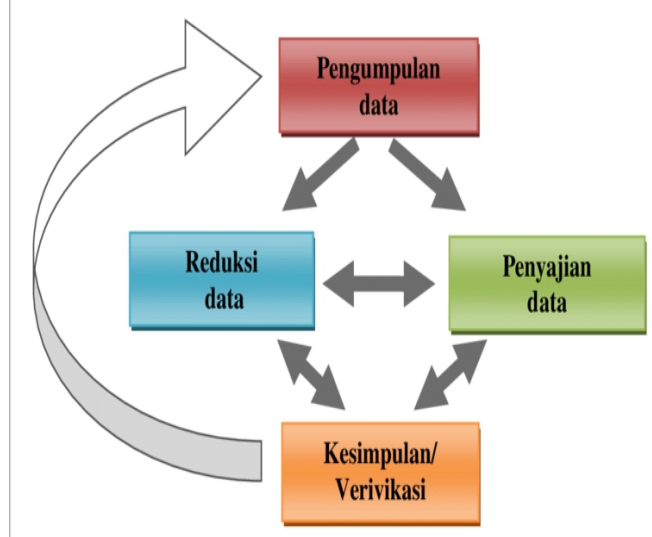

Gambar 1.1 Model Analisis Interaktif ${ }^{[8]}$ Dalam proses ini kegiatan yang pertama adalah proses pengumpulan data. Sebagian besar data kualitatif adalah data yang berupa kata-kata, fenomena, foto, sikap, dan perilaku keseharian yang diperoleh peneliti dari hasil observasi mereka dengan menggunakan beberapa teknik seperti obeservasi, wawancara, dokumentasi dan dengan menggunakan alat bantu yang berupa kamera, video tape ${ }^{[9]}$.

\section{HASIL PEMBAHASAN DAN}

$$
\text { PENELITIAN }
$$

3.1 Peran Orang Tua dalam

Pendidikan Agama pada Keluarga
Anak Usia Sekolah Dasar di
Dusun Candi Rejo, Desa
Sardonoharjo
Peran orang tua dalam
pendidikan agama pada keluarga menjadi peran yang sangat penting bagi setiap keluarga. Pendidikan keluarga menjadi peran yang paling utama bagi anak-anak dalam membekali diri anak untuk mendapatkan transformasi pengetahuan, pembelajaran, dan pembiasaan akhlak di dalam lingkungan keluarga. Keluarga merupakan unit sosial terkecil yang memiliki peran 
penting dalam pembentukan karakter bangsa. Keluarga akan membentuk karakter seseorang dan berpengaruh pada lingkungannya. Sebaliknya, jika karakter itu tidak baik, ia akan berpengaruh luas kepada lingkungannya. Bahkan, pada akhirnya akan menjelma menjadi karakter bangsa.

Oleh sebab itu keluarga memiliki peran yang sangat penting dalam mewarnai sukses tidaknya pengembangan karakter anak antara lain terletak pada model pendidikan karakter yang di berikan oleh orang tua terhadap anaknya., namun umumnya penyelenggaraan pendidikan karakter dalam keluarga secara operasional maupun proseduralnya belum menjadi perhatian serius para orangtua.

Pendidikan yang di mulai dari keluarga dapat menyangkut dalam penanaman nilai-nilai keislaman, yang menjadi tolak ukur dalam membentuk karakter anak melalui lingkungan keluarga, terlebih saat ini, pendidikan formal kita telah di cap "kurang berhasil" dalam membangun karakter anak bangsa. Jika pendidikan formal sudah di ragukan keberhasilannya, lalu ke mana lagi harapan dalam pembentukan karakter anak, yaitu di dalam keluarga menjadi hal yang paling utama dalam pembentukan karakter pada saat ini.

Berdasarkan kegiatan yang di lakukan peneliti dapat mengambil beberapa contoh konkrit dari peran orang tua dalam pendidikan keluarga pada anak usia sekolah dasar di Dusun Candi Rejo. Peneliti melihat ada beberapa cara yang di lakukan oleh orang tua di Dusun Candi Rejo dalam membangun dan menerapkan peran pendidikan keluarga kepada anak-anak nya dalam menanamkan ibadah shalat dan membaca Al-quran kepada anak di anatara lain, menawarkan mondok sejak lulus sekolah dasar, merayu dengan hadiah, memberikan hukuman bila tidak melaksanakannya, menghantarkan anak, memberikan uang saku agar anak bersemangat dalam beribadah, memberikan tauladan orang tua agar anak dapat mencontoh orang tuanya, mengajarkan ibadah anak di rumah, dan melakukan pemantauan kepada anak ${ }^{[10]}$. Dalam Kegiatan wawancara Peneliti mewawancarai dusun Candi
Rejo dengan 2 rt yaitu rt 01 dan rt 02 mengungkapkan mengenai peran orang tua dalam pendidikan agama pada keluarga, dengan informan pertama yaitu, Bapak Zam Zami dan Ibu Dalin mengatakan:

"Setiap hari memantau shalat anak dengan mengingatkan, mengajak, menasehati, dan memberikan hukuman kepada anak apabila tidak melaksanakan shalat. Alhamdulillah sekarang sudah lima waktu shalatnya, dulu disaat masih kecil masih sering bolong-bolong ketika Bapak sedang kerja dan tidak ada di rumah, dulu sekedar menjalankan saja karena takut dengan orang tua. Jika waktunya TPA, mengingatkan kepada anak agar segera siap-siap. Untuk membaca Al-Qur'an jika orang tuanya sendiri yang mengajari di rumah agak susah, anak lebih senang belajar di TPA dengan mas dan mbak pengajar TPA. Kalau di rumah biasanya ngaji dengan Ibunya setiap habis shalat magrib"[11].

Berdasarkan pengamatan peneliti mengenai peran orang tua dalam pendidikan agama pada keluarga. Beberapa keluarga memiliki cara-cara yang berbeda dalam memberikan pendidikan keluarga kepada anaknya, dengan beberapa faktor pemikiran dan kesibukan dari orang tua nya masingmasing. Pada peran orang tua yang memang rutinitas dalam bekerja seharihari, lebih memilih dan mentransformasikan peran nya dengan cara pemantauan, memanggil guru privat ke rumah, memasukan anak ke pondok jika sudah lulus Sekolah Dasar dan memberikan semangat kepada anaknya dalam melakukan pendidikan agama, dengan semisal belajar TPA, shalat berjamaah di masjid, dan mengaji. Hasil ini di dapat dengan mewawancarai informan kedua. Wawancara selanjutnya Bapak Joni Prasetyo dan Ibu Dyah Esti informan mengungkapkan mengenai peran orang tua dalam pendidikan agama pada keluarga.

"Pertama, kita memberikan contoh kepada anak dengan mengajari shalat dan membaca 
Al-Qur'an. Kedua, dengan cara memberikan dan memanfaatkan fasilitas yang ada di lingkungan sekitar misalnya dengan adanya TPA kita ikutkan anak ikut TPA, jika anak ingin les mengaji privat maka kami juga mengupayakan untuk mendatangkan guru untuk belajar mengaji di rumah. Terlebih jika anak setelah lulus SD nanti mau tinggal di pondok pesantren maka orang tua sangat mendukung disamping keterbatasan ilmu yang orang tua miliki, karena di pondok pesantren belajar agamanya bisa lebih optimal daripada di rumah. Namun kita tidak memaksa, sesuai dengan keinginan anak bagaimana"[12].

Berdasarkan pengamatan peneliti mengenai peran orang tua dalam pendidikan agama pada keluarga. Keluarga yang memiliki kegiatan lebih banyak di rumah memiliki cara yang berbeda dalam perannya kepada anak dalam pendidikan agama. keluarga yang kesibukan sangat banyak di rumah lebih membuat anak menjadi tambah dekat dan optimal dalam mentransformasikan kegiatan yang di lakukan oleh anak. Bahkan orang tua yang menjadi sumber dalam menambahkan pemahaman nilainilai keislaman kepada anak dan tidak hanya di tempat TPA, mengaji, dan shalat berjamaah di masjid. Selagi ketika anak sedang malas melakukan ibadah, orang tua dapat langsung merayu anak agar bersemangat kembali melakukan pendidikan agama yang anak lakukan di luar dari pembelajaran nilai-nilai keislaman di keluarga. Orang tua juga dapat menghantarkan anak ke tempat pembelajaran TPA, shalat berjamaah di masjid, dan menambah pembelajaran mengaji di rumah bersama orang tua. Dengan hal ini, hasil penelitian di dapat melalui informan ketiga dan keempat. Wawancara selanjutnya Bapak Sumarwan dan lbu Dasinem informan mengungkapkan mengenai peran orang tua dalam pendidikan agama pada keluarga.

"Saya sebagai orang tua biasanya dengan cara mengajak mengaji nanti menyimak bacaan anak dan membenarkan jika ada yang salah, namun jika sudah benar bacaannya maka tinggal dilanjutkan saja. Alhamdulillah kalau untuk shalat anak sudah mau tertib lima waktu"[13].

Wawancara selanjutnya Bapak Dahlan dan Ibu Ngadilah informan mengungkapkan mengenai peran orang tua dalam pendidikan agama pada keluarga.

"Merayu anak semampunya, setiap masuk waktu shalat dan TPA diingatkan. Setiap saat anak harus diingatkan sebagai orang tua. Karena setiap anak adalah amanah dari Allah Swt, kita sebagai orang tua juga harus bertanggung jawab mendidiknya. Mengajari anak shalat sejak usia dini dan menyimak bacaan AlQur'an anak setelah shalat maghrib jika ada kesempatan, saya kan sambil jaga warung jadi tidak selalu rutin bisa menyimak anak mengaji, biasanya anak disimak oleh bapak"[14].

Wawancara selanjutnya Bapak Kardiyono dan Ibu Isthikarah informan mengungkapkan mengenai peran orang tua dalam pendidikan agama pada keluarga.

"Dengan cara mengantarkan anak ke tempat mengaji, diberikan uang saku ketika berangkat TPA, diajak shalat ketika waktu shalat sudah tiba"[15].

Keluarga memiliki peranan yang sangat penting dalam upaya mengembangkan pribadi anak. Perawatan orang tua yang penuh kasih saying dan pendidikan tentang nilai-nilai kehidupan, baik agama maupun sosial budaya yang di berikannya merupakan faktor yang kondusif untuk mempersiapkan anak menjadi pribadi yang sehat. Keluarga juga di pandang sebagai institusi yang dapat memenuhi kebutuhan insan (manusiawi), terutama kebutuhan bagi pengembangan kepribadian anak dan pengembangan ras manusia. Apabila mengaitkan peranan keluarga dengan kebutuhan individu dari Maslow, maka keluarga merupakan lembaga pertama yang dapat memenuhi kebutuhan tersebut, baik kebutuhan fisik-biologis maupun sosio-psikologisnya ${ }^{[16]}$. Moehammad Isa 
Soelaeman mengemukakan, keluarga itu hendaknya berperan sebagai pelindung dan pendidik angota-anggota keluarganya, sebagai penghubung mereka dengan masyarakat, sebagai pencukup kebutuhan-kebutuhan ekonominya, sebagai pembina kehidupan religiusnya, sebagai penyelengara rekreasi keluarga dan pencipta suasana yang aman dan nyaman bagi seluruh anggota keluarga dan khusunya bagi suami dan istri sebagai tempat memenuhi kebutuhankebutuhan biologisnya ${ }^{[17]}$. Adapun pola dan pelaksanaan peranan keluarga hendaknya sejalan dengan fungsi-fungsi keluarga sebagaimana dijelaskan oleh para ahli sebagai berikut : Fungsi edukasi, fungsi proteksi, fungsi afeksi, fungsi sosialisasi, fungsi reproduksi, fungsi religi, fungsi ekonomi, fungsi rekreasi, fungsi biologis, fungsi transformasi[18].

\subsection{Faktor Pendukung dan Faktor \\ Penghambat Pelaksanaan Peran Orang Tua dalam Pendidikan Agama Pada Keluarga Anak Usia Sekolah Dasar di Dusun Candi Rejo, Desa Sardonoharjo}

Penanaman nilai-nilai karakter pada anak dalam keluarga adalah motivasi, motivasi didefinisikan oleh Maslow sebagai proses psikologikal seseorang yang menyebabkan terjadinya perbuatan-perbuatan secara sukarela yang diarahkan untuk mencapai tujuan tertentu[199. Kegiatan Observasi peneliti terhadap bentuk faktor pendukung dan penghambat pelaksanaan peran orang tua dalam pendidikan agama pada keluarga anak usia sekolah dasar di Dusun Candi Rejo Desa Sardonoharjo. Dalam kegiatan observasi dan wawancara peneliti, faktor pendukung dan penghambat bagi peran orang tua kepada anak memiliki berbagai macam perbedaan dalam mentransformasikan faktor pendukung peran orang tua dalam pendidikan agama dan faktor penghambat dalam pendidikan agama. Faktor pendukung yang sangat mempengaruhi peran orang tua dalam pendidikan agama kepada anak, yaitu memberi semangat kepada anak dengan memberikan sebuah hadiah, menasehati anak secara lembut, teman dalam mengajak ke dalam pendidikan agama (TPA, Shalat, Mengaji), dekat dengan masjid, dan orang tua menjadi tauladan bagi anak nya agar dapat di contoh ${ }^{[20]}$.

Hal itu didukung oleh wawancara peneliti terhadap informan dari beberapa yang kami wawancarai Bapak Zam Zami dan Ibu Dalin mengungkapkan mengenai faktor pendukung peran orang tua dalam pendidikan agama pada keluarga anak usia sekolah dasar, mengungkapkan :

"Faktor yang paling
mempengaruhi yaitu $\begin{array}{r}\text { dekat } \\ \text { dengan masjid sehingga }\end{array}$
mendukung anak untuk ikut shalat berjamaah dan mengikuti TPA"[21]. Wawancara selanjutnya Bapak Yukri Asrodi dan lbu Dati mengungkapkan mengenai faktor pendukung peran orang tua dalam pendidikan agama pada keluarga anak usia sekolah dasar, mengungkapkan :

"Memberi semangat kepada anak, ketika anak menginginkan sesuatu misalnya meminta dibelikan makanan kepada orang tua. Sehingga anak menjadi bersemangat ketika melakukan apa yang orang tua inginkan untuk berangkat shalat dan mengaji"'[22].

Wawancara selanjutnya Bapak Joni Prasetyo dan Ibu Dyah Esti mengungkapkan mengenai faktor pendukung peran orang tua dalam pendidikan agama pada keluarga anak usia sekolah dasar, mengungkapkan :

"Pertama dari diri kita sendiri dengan mengajak anak maka anak akan mengikuti kita.Kedua, banyak teman seusianya yang mengaji di TPA akhirnya motivasi orang tua dengan temantemannya mendukung sehingga dia juga melaksankan"[23].

Selain faktor pendukung peran orang tua dalam pendidikan agama pada keluarga anak usia sekolah dasar. Faktor penghambat peran orang tua dalam pendidikan agama pada keluarga anak usia sekolah menjadi sebuah urgensi yang menjadi anak-anak kurang semangat dan menurunya imunitas dalam mencari ilmu pendidikan sebanyak mungkin bagi anak-anak. Beberapa faktor penghambat peran 
orang tua dalam pendidikan agama pada keluarga anak usia sekolah dasar antara lain, bermain dengan teman sehingga lupa waktu untuk melakukan TPA, Mengaji, dan shalat, kurang nya rasa semangat dalam melakukan kegiatan pendidikan agama, mengulurwaktu menjadi alasan anak dalam faktor penghambat, dan bermain game menjadi paling urgensi dalam faktor penghambat peran orang tua dalam pendidikan agama pada keluarga anak usia sekolah ${ }^{[24 !}$.

Hal itu didukung oleh wawancara peneliti terhadap informan dari beberapa yang kami wawancarai Bapak Zam Zami dan Ibu Dalin mengungkapkan mengenai faktor penghambat peran orang tua dalam pendidikan agama pada keluarga anak usia sekolah dasar, mengungkapkan :

"Biasanya bermain dengan teman-temannya, kan dia punya banyak mainan. Dan biasanya kalau sudah main, waktunya shalat tapi belum pulang, masih di rumah temannya"[25].

Wawancara selanjutnya Bapak Yukri Asrodi dan Ibu Dati mengungkapkan mengenai faktor penghambat peran orang tua dalam pendidikan agama pada keluarga anak usia sekolah dasar, mengungkapkan :

"Biasanya jika TPA, ketika dalam keadaan marah sebelum waktu TPA maka anak tidak mau berangkat TPA. Tapi kalau untuk shalat, meskipun anak dalam keadaan marah tetap shalat karena hal itu merupakan suatu kewajiban"[26].

Wawancara selanjutnya Bapak Sumarwan dan lbu Dasinem mengungkapkan mengenai faktor penghambat peran orang tua dalam pendidikan agama pada keluarga anak usia sekolah dasar, mengungkapkan :

"Yang pertama ketika waktu shalat sudah selesai namun belum makan, biasanya anak mau makan dulu, yang kedua karena adanya sarana dan prasarana rusak misalnya saat ini sepedanya rusak karena bannya bocor. Yang ketiga ketika main game di HP"[27].

\begin{abstract}
Wawancara selanjutnya Bapak Supriyatno dan Ibu Juminem mengungkapkan mengenai faktor penghambat peran orang tua dalam pendidikan agama pada keluarga anak usia sekolah dasar, mengungkapkan :

"Biasanya ketika main sepak bola dengan teman-temannya, sehingga terlambat berangkatnya. Selain itu disaat ketiduran sehingga lupa tidak shalat dan TPA"[28].
\end{abstract}

Berdasarkan pengamatan peneliti mengenai faktor pendukung dan faktor penghambat pelaksanaan peran orang tua dalam pendidikan agama pada keluarga anak usia sekolah dasar di Dusun Candi Rejo Desa Sardonoharjo. Konsep dan persepsi pada diri seorang anak di pengaruhi oleh unsur dari luar diri mereka. Hal ini terjadi karena anak usia dini telah melihat, mendengar, mengenal, dan mempelajari hal-hal yang berada dalam diri mereka. Mereka telah melihat dan mengikuti apa-apa yang dikerjakan dan diajarkan orang dewasa dan orang tua mereka tentang sesuatu. Dalam kehidupan sehari-hari perilaku yang dilakukan anak-anak pada dasarnya lebih banyak mereka peroleh dari meniru. Shalat berjamaah misalnya, mereka lakukan sebagai hasil dari melihat perbuatan itu di lingkungannya, baik berupa pembiasaan ataupun pengajaran khusus yang intensif. Sehingga, sifat meniru yang di miliki anak ini merupakan modal yang positif dan potensial dalam pendidikan karakter bagi anak. Agar seorang anak meniru sesuatu yang positif dari orangtua ataupun orang yang dianggap ia idolakan, maka menjadi kemestian mereka itu harus menjadikan dirinya sebagai tauladan yang baik dengan menampilkan diri sebagai sumber norma, budi yang luhur dan perilaku yang mulia. Dengan demikian, ketaatan kepada ajaran agama ataupun perilaku positif lainnya merupakan kebiasaan yang menjadi milik mereka, yang di pelajari dari guru maupun orang tua.

Di samping itu, tiga syarat penting dalam proses mendidik karakter anak, yang pertama adalah cinta, kedua adalah kepercayaan, ketiga adalah kewibawaan. Ketiga syarat ini saling mempengaruhi dan saling terkait. Cinta 
akan menimbulkan kepercayaan, kepercayaan akan menghadirkan kewibawaan, kewibawaan adalah kemampuan untuk dapat mempengaruhi orang lain. Kewibawaan akan lahir jika ada kepercayaan. Kepercayaan akan muncul jika ada keteladanan[29].

Maka dari itu sebagai orang tua, sejatinya selalu ada dalam dirinya melekat semangat transformasi ilmu dan transformasi nilai. Sebab, jika tidak seimbang, orang tua atau suatu institusi pendidikan hanya mengisi dimensi intelektualnya semata, namun mengabaikan dimensiemosional dan etika anak-anaknya. Untuk itu, para orang tua ataupun pendidik selain cerdas dan terampil dalam mentransfer ilmu pengetahuan sekaligus menjadi sosok "yang digugu dan ditiru". Sebaliknya, jika tidak demikian, orang tua ataupun pendidik yang tidak memiliki dimensi keteladanan akan menjadi sosok yang tidak mendapat rasa simpatik dari anak-anaknya.

\subsection{Dampak Peran Orang Tua dalam \\ Pendidikan Agama pada Keluarga \\ Anak Usia Sekolah Dasar di \\ Dusun Candi Rejo, Desa \\ Sardonoharjo}

Pembiasaan-pembiasaan perilaku seperti melaksanakan nilai-nilai ajaran islam (beribadah), membina hubungan atau interaksi yang harmonis dalam keluarga, memberikan bimbingan, arahan, pengawasan dan nasehat merupakan hal yang senantiasa harus dilakukan oleh orang tua agar perilaku anak yang menyimpang dapat dikendalikan. Abdurahman An-Nahlawi menyatakan bahwa metode pendidikan dan pembinaan karakter yang perlu diterapkan oleh orang tua dalam kehidupan keluarga dari sekian banyak cara itu adalah metode pembiasaan, yang jika dilaksanakan akan menguatkan karakter mulia ${ }^{[30]}$.

Dari uraian beberapa di atas kebiasaan memainkan peranan sangat penting bagi kehidupan seorang anak. Dari kebiasaan-kebiasaan itu kita dapat melihat bagaimana kemungkinan kehidupan seorang anak di masa depan. Kalau seorang anak memiliki kebiasaan yang baik tentu akan menghantarkan kepada kehidupan yang baik dan bahagia, tetapi ketika seorang anak memiliki kebiasaan-kebiasaan yang buruk kemungkinan besar kehidupan yang bersangkutan ke depan tidak akan sesuai dengan yang dia harapkan. Hal ini sejalan dengan bunyi sebuah pepatah, "Orang-orang tidak bisa menentukan masa depan. Mereka menentukan kebiasaan, dan kebiasaan menentukan masa depan."[31]

Berdasarkan kegiatan yang di lakukan peneliti dapat mengambil beberapa contoh konkrit dari dampak peran orang tua dalam pendidikan agama pada keluarga anak usia sekolah dasar di Dusun Candi Rejo. Peneliti melihat ada beberapa cara yang di lakukan oleh orang tua di Dusun Candi Rejo dalam mendidik anak agar di lingkungan luar berdampak lebih baik dengan memperoleh hasil antara lain sebagai berikut yaitu orang tua masih belum bisa mengukur perilaku anak yang terkadang masih naik turun belum stabil, anak terkadang mudah diberitahu terkadang juga susah diberitahu, anak dapat menghormati orang tua dan tetangga, anak cenderung pemalu dan pendiam jika belum akrab dengan orang lain, anak menjadi tidak mudah terpengaruh pergaulan yang buruk dari lingkungan sekitar, sebagai bekal anak di masa yang akan datang ${ }^{[32]}$.

Dalam Kegiatan wawancara Peneliti mewawancarai dusun Candi Rejo dengan 2 rt yaitu rt 01 dan rt 02 mengungkapkan mengenai dampak peran orang tua dalam pendidikan agama pada keluarga, dengan informan pertama yaitu, Bapak Zam Zami dan Ibu Dalin mengatakan:

"Kalau untuk saat ini karena masih anak-anak sebagai orang tua masih belum bisa mengukur, masih naik turun, kadang menurut kadang susah dibilangin"[33].

Wawancara selanjutnya informan Bapak Yukri Asrodi dan lbu Dati mengungkapkan mengenai dampak peran orang tua dalam pendidikan agama pada keluarga.

"Anak akan menjadi baik jika pembelajaran mengenai ibadah dilakukan di dalam rumah sebagai bekal di lingkungan, jika tidak dibekali dengan pendidikan keagamaan di keluarga 
ditakutkan anak berdampak tidak baik di lingkungan masyarakat"[34].

Wawancara selanjutnya Bapak Dahlan dan Ibu Ngadilah informan mengungkapkan mengenai dampak peran orang tua dalam pendidikan agama pada keluarga.

"Menghormati orang tua dan juga orang lain di sekitarnya, sopan santunnya juga sudah baik. Namun terkadang sikapnya juga masih labil, masih belum stabil"[35]. Dampak akan terealisasi di dalam masyarakat mengenai baik dan buruk nya anak tergantung dari pembelajaran orang tua yang menegakkan tata aturan, pembiasaan, peneladanan, pemotivasian, dan pengajaran di dalam keluarga. Banyak orang tua lemah dalam penegakkan disiplin, baik terhadap anggota keluarga, terlebihlebih terhadap dirinya sendiri. Ketidaktegasan menegakkan aturan mengakibatkan banyaknya pelanggaran kesepakatan dan menciptakan ruang toleransi yang berlebihan sehingga mendorong suasana rumah tangga jauh dari keteraturan. Oleh karena itu, kewajiban penghuni rumah untuk menciptakan peraturan yang jelas dan menegakkan aturan tersebut terhadap setiap individu tanpa pandang bulu, agar menghasilkan dampak yang signifikat kepada anak di dalam kehidupan yang berjiwa religious dan memiliki akhlak yang baik.

\section{KESIMPULAN}

Setelah menguraikan panjang lebar dari bab pertama sampai bab akhir, hasil laporan penelitian ini dapat disederhanakan dengan beberapa kesimpulan yang berdasarkan atas hasil uraian dan analisa data yang diperoleh melalui wawancara, observasi, dan dokumentasi yang dijelaskan pada pembahasan tertentu terdahulu sebagai jawaban atas fokus penelitian dan pertanyaan penelitian, maka penulis dapat menarik kesimpulan bahwa :

a. Keluarga yang tidak banyak kegiatan di rumah lebih membuat anak menjadi tambah dekat dan optimal dalam mentransformasikan kegiatan yang di lakukan oleh anak. Orang tua yang menjadi sumber dalam menambahkan pemahaman nilai-nilai keislaman kepada anak dan tidak hanya di tempat TPA, mengaji, dan shalat berjamaah di masjid. Ketika anak sedang malas melakukan ibadah, orang tua dapat langsung merayu anak agar bersemangat kembali melakukan pendidikan agama yang anak lakukan di luar dari pembelajaran nilai-nilai keislaman di keluarga. Orang tua juga dapat menghantarkan anak ke tempat pembelajaran TPA, shalat berjamaah di masjid, dan menambah pembelajaran mengaji di rumah bersama orang tua.

b. Faktor pendukung yang sangat mempengaruhi peran orang tua dalam pendidikan agama kepada anak, yaitu memberi semangat kepada anak dengan memberikan sebuah hadiah, menasehati anak secara lembut, teman dalam mengajak ke dalam pendidikan agama (TPA, Shalat, Mengaji), dekat dengan masjid, dan orang tua menjadi tauladan bagi anak nya agar dapat di contoh.

c. Faktor penghambat peran orang tua dalam pendidikan agama pada keluarga anak usia sekolah dasar antara lain, bermain dengan teman sehingga lupa waktu untuk melakukan TPA, Mengaji, dan shalat, kurang nya rasa semangat dalam melakukan kegiatan pendidikan agama, mengulurwaktu menjadi alasan anak dalam faktor penghambat, dan bermain game menjadi paling urgensi dalam faktor penghambat peran orang tua dalam pendidikan agama pada keluarga anak usia sekolah.

d. Peneliti melihat cara yang di lakukan oleh orang tua di Dusun Candi Rejo dalam mendidik anak agar di lingkungan luar berdampak lebih baik dengan memperoleh hasil yaitu orang tua masih belum bisa mengukur perilaku anak yang terkadang masih naik turun belum stabil, anak terkadang mudah diberitahu terkadang juga susah diberitahu, anak dapat menghormati orang tua dan tetangga, anak cenderung pemalu dan pendiam jika belum akrab dengan orang lain, 
anak menjadi tidak mudah terpengaruh pergaulan yang buruk dari lingkungan sekitar, sebagai bekal anak di masa yang akan datang.

\section{SARAN}

Saran yang dimaksud adalah sebagai bahan pertimbangan bagi semua pihak dalam rangka perbaikan dan penyempurnaan Peran Orang Tua Dalam Pendidikan Agama pada Keluarga Anak Usia Sekolah Dasar di Dusun Candi Rejo, Desa Sardonoharjo, Ngaglik, Sleman. Agar nanti nya orang tua khusus nya di rt 01 dan 02 Dusun Candi Rejo dapat secara optimal dalam melakukan peran nya pada pendidikan agama ke anak-anaknya. Saran-saran tersebut antara lain :

a. Peneliti menghimbau kepada orang tua lebih diutamakan pemantauan terhadap anak di dalam kehidupan bagi para orang tua yang bekerja sehingga, perkembangan anak dalam pendidikan agama di lingkungan keluarga di transformasikan secara optimal jika langsung di pantau oleh orang tua.

b. Peneliti juga menghimbau kepada penegakkan aturan di setiap keluarga yang di buat oleh orang tua, sehingga adanya kedisplinan buat anak. Karena dengan tidak adanya ketidaktegasaan yang di buat oleh orang tua mangakibatkan banyaknya pelanggaran kesepakatan dan menciptakan ruang toleransi yang berlebihan sehingga mendorong suasana keluarga jauh dari keteraturan.

c. Peneliti menghimbau kepada orang tua agar dapat membiasakan dan selalu memotivasi anak-anak nya di dalam bidang pendidikan agama dan bidang lainnya, agar anak memiliki semangat dalam melakukan hal yang anak senangi. Agar tidak ada keterpaksaan dalam melakukan kreatifitas dan inovasi di anak, yang membuat anak menjadi malas dan bosan dalam kehidupannya.

\section{DAFTAR PUSTAKA}

1. Sugiyono, Metode Penelitian Kuantitatif, Kualitatif, dan R\&D, (Bandung: Alfabeta, 2013), hal. 2.

2. Azwar Saifuddin, Metode Penelitian, (Yogyakarta: Pustaka Pelajar, 2007), hal. 5 .

3. Ibid, hal. 7 .

4. Sugiyono, Memahami Penelitian Kualitatif, (Bandung: Alfabeta, 2013), hal. 125.

5. Prastowo, Andi, Menguasai TeknikTeknik Koleksi Data Penelitian Kualitatif, (Yogyakarta: Diva Press, 2010), hal. 289.

6. Gambar. 1 Triangulasi teknik di ambil dari buku : Prastowo, Andi, Menguasai Teknik-Teknik Koleksi Data Penelitian Kualitatif, (Yogyakarta: Diva Press, 2010), hal. 289.

7. Prastowo, Andi, Menguasai TeknikTeknik Koleksi Data Penelitian Kualitatif, (Yogyakarta: Diva Press, 2010), hal. 289.

8. Description : Model Analisis Interaktif Miles dan Huberman (1984:23)

9. Satori, Djam'an, Metodologi Penelitian Kualitatif, (Bandung: Alfabeta, 2009), hal. 171.

10. Observasi pengamatan di lingkungan dalam Rt 01 dan Rt 02 di Dusun Candi Rejo, 1-2 April 2020.

11. Bapak Zam Zami dan Ibu Dalin di Dusun Candi Rejo, Rabu, 08 April 2020

12. Bapak Joni Prasetyo dan Ibu Dyah Esti di Dusun Candi Rejo, Kamis, 09 April 2020

13. Bapak Sumarwan dan Ibu Dasinem di Dusun Candi Rejo, Kamis, 09 April 2020

14. Bapak Dahlan dan Ibu Ngadilah di Dusun Candi Rejo, Kamis, 09 April 2020

15. Bapak Kardiyono dan Ibu Isthikarah di Dusun Candi Rejo, Jum'at, 10 April 2020

16. Amirrulloh Syarbini, "Pendidikan Karakter Berbasis Keluarga", (Yogyakarta : Ar- Ruzz Media, 2016) hal. 75 .

17. Moehammad Isa Soelaeman, Pendidikan dalam Keluarga. (Bandung: Alfabeta. 1994) hal. 125.

18. Amirrulloh Syarbini, "Pendidikan Karakter Berbasis Keluarga", 
(Yogyakarta : Ar- Ruzz Media, 2016) hal. 76

19. A. H. Maslow, Motivation and personality, (New York: Harper and Row, 1984), hal 24.

20. Observasi pengamatan di lingkungan dalam Rt 01 dan Rt 02 di Dusun Candi Rejo, 6-7 April 2020.

21. Bapak Zam Zami dan Ibu Dalin di Dusun Candi Rejo, Rabu, 08 April 2020

22. Bapak Yukri Asrodi dan Ibu Dati di Dusun Candi Rejo, Rabu, 08April 2020

23. Bapak Joni Prasetyo dan Ibu Dyah Esti di Dusun Candi Rejo, Kamis, 09 April 2020

24. Observasi pengamatan di lingkungan dalam Rt 01 dan Rt 02 di Dusun Candi Rejo, 6-7 April 2020.

25. Bbapak Zam Zami dan Ibu Dalin di Dusun Candi Rejo, Rabu, 08 April 2020

26. Bapak Yukri Asrodi dan Ibu Dati di Dusun Candi Rejo, Rabu, 08April 2020

27. Bapak Sumarwan dan Ibu Dasinem di Dusun Candi Rejo, Kamis, 09 April 2020

28. Bapak Supriyatno dan Ibu Juminem di Dusun Candi Rejo, Kamis, 09 April 2020

29. Rahmi Adiyati, "Mendidik dengan keteladanan", dalam Republika, edisi 20 Agustus 2006, hal 12.

30. Abdurrahman an-Nahlawi, Prinsipprinsip dan Metode Pendidikan Islam di Keluarga, Sekolah, dan Masyarakat, terj. Moehammad Dahlan dan Soelaeman (Bandung: CV. Diponegoro, 1996), hal 188.

31. Darmadi Darmawangsa, Fight Like A Tiger, Win Like A Champion (Jakarta: Elex Media Komputindo, 2006), hal 132.

32. Observasi pengamatan di lingkungan dalam Rt 01 dan Rt 02 di Dusun Candi Rejo, 6-7 April 2020.

33. Bapak Zam Zami dan Ibu Dalin di Dusun Candi Rejo, Rabu, 08 April 2020

34. Bapak Yukri Asrodi dan Ibu Dati di Dusun Candi Rejo, Rabu, 08 April 2020

35. Bapak Dahlan dan Ibu Ngadilah di Dusun Candi Rejo, Kamis, 09 April 2020 